\title{
Peripheral Blood Stem Cell
}

National Cancer Institute

\section{Source}

National Cancer Institute. Peripheral Blood Stem Cell. NCI Thesaurus. Code C12946.

An immature (progenitor) cell circulating in the peripheral blood. It has the capacity for replication and differentiation to mature blood cells. 